\title{
Embracing Multiple Facets of Disability Enquiry in ASEAN Societies: Learning from Critical Theory and Postmodernism
}

ORIGINAL ARTICLE

\author{
Chi Cheng, $\mathbf{W u}^{1}$; Herli Salim², and Jiraporn $\mathrm{Chano}^{3}$ \\ ${ }^{I}$ Teacher Education Center, Tainan University of Technology, Taiwan \\ ${ }^{2}$ Universitas Pendidikan Indonesia Kampus Serang, Indonesia \\ ${ }^{3}$ Mahasarakham University, Thailand
}

\section{ARTICLE INFO}

Article history

RECEIVED: 09-Sep-19

REVISED: 07-Oct-19

ACCEPTED: 04-Dec-19

PUBlished: $16-$ Dec-19

*Corresponding Author:

Email: deakinroy@gmail.com

\begin{abstract}
This article aims to introduce three research methodologies (i.e., emancipatory research, disability race critical theory [DisCrit], and narrative research) to increase multiple facets of disability enquiry in the Association of Southeast Asian Nations societies. Drawing from the doctrines of critical theory and postmodernism, these methodologies focus on addressing political issues of knowledge and social mechanism. The first methodology, emancipatory research, sees researching as a political activism with an attempt of dismantling current oppressive knowledge and mechanism. Furthermore, DisCrit provides a useful framework to critically scrutinize the intersection of race and disability. Finally, postmodernism-grounded narrative research is introduced because it can provide authentic voices of disabled people and avoid the monopoly of voices by particular groups of people. Hopefully, enriching research facets of disability enquiry will lead to more comprehensive considerations on social situations of disabled people and further improve their social welfares.
\end{abstract}

Keywords: Critical theory, Disability, Postmodernism, Research methodology

\section{Situating Research Issues}

The Association of Southeast Asian Nations (ASEAN) was initially established in 1967 with the aim to facilitate political, economic, and security collaborations within the region. In 1997, it expanded to include ten Member States of Nations, Brunei, Cambodia, Indonesia, Laos, Malaysia, Myanmar, the Philippines, Singapore, Thailand, and Vietnam (ASEAN, 2019). In recent years the promotion of the welfare of disabled people has become one of the significant agendas. This is demonstrated in the official documents, such as the ASEAN Human Rights Declaration in 2012, and action plans, such as the Mobilization Framework of the ASEAN Decade of Persons with Disabilities (2011-2020) (United Nations Economic \& Social Commission for Asian \&the Pacific, 2012).

The research practice reflects the improvement of welfare of disabled people in some ASEAN countries. In a comprehensive review of inclusive education, Nishio,
Tomokawa' Kobayashi, Mizoue, Horita and Yamamoto (2017) analyzed the online English studies published in 1995 to 2015 in ASEAN. Twenty-two of a total of 27 studies defined, were published after 2005. That is, inclusive education has received a higher profile over the past decade. This was particularly significant in Malaysia and Singapore, given $78 \%$ of the studies was conducted in both counties. Lee \& Low's (2014) review also figured out that the educational right of disabled students in Malaysia has advanced in terms of legislation, policy, funding, teacher training, resources, and multidisciplinary collaboration, etc.

On the other hand, it is obvious that positivist threads have framed researchers' considering and building social mechanism relating to disabled people. In a sense, positivism prompts researchers to believe in rationality and empiricism while investigating what disability is, what causes disability, and how to address disability (Gallagher, 1998; Kauffman \& Sasso, 2006). The binary of normal or 
disabled has fueled the parallel system and may impede the inclusion of disabled people in mainstream communities (Annamma, Boele, Moore, Klingneer, 2013; Wu, 2013).

However, positivism has been facing profound challenges with the genesis of critical theory and postmodernism in Western societies in the middle of the last century (Elkind, 1997). Researchers now have become more aware of and reflective on political consequences of knowledge and the dominance of social mechanism on disabled people (Gabel \& Connor, 2009).

In contrast, in many ASEAN societies, there is not much attention paid to involving critical theory and postmodernism in the discussions of the issues concerning disabled people. Positivism is still viewed as a supreme voice in doing research about disability. This might restrain the multiple facets of research practice and may silence the voices of disabled people.

Therefore, this article attempts to bridge this gap by introducing three main research methodologies: emancipatory research, DisCrit, and narrative research. The former two methodologies are strongly connected to critical theory and the last one is framed on postmodernism, respectively. The article is composed of two main parts: introduction of basic ideas of positivism, critical theory as well as postmodernism, and the introduction of the three relevant methodologies.

\section{Positivism, Critical Theory and Postmodernism}

The epistemology of a philosophy concerns with the nature of reality or truth and the way to approach it. The epistemological differences urge positivism, critical theory and postmodernism to take different or even contradictory perspectives on the objectivity/subjectivity of the truth and the neutrality/bias of researchers' positions in doing research (Crotty, 1998).

Positivism postulates that reality exists universally, objectively and independently outside personal experiences and can be discovered through scientific methods. In doing research, humane behaviors and contextual situations are generally reduced to limited and observable variables. Then, different statistical techniques are sought to testify their relationships and a causal or corelational relationship may be built. Positivists optimistically believe that social phenomenon could be eventually described, explained, predicted, and controlled as increments of empiricist knowledge (Crotty, 1998). In a sense, the difficulties experienced by disabled people, would be gradually eliminated or elevated as culmination of the knowledge and advancements of technologies (Kauffman \& Sasso, 2006).

Nevertheless, the optimistic and increment-focused perspective has experienced pervasive challenges from critical theory and postmodernism-both of which are intellectual developments in Western societies. Both theories reject the objectivity of knowledge, recognize ideology and power as crucial factors in forming knowledge, and concern the political consequences of knowledge. As such, a call for reconstruction of knowledge and social mechanism are seen as necessary to improve the welfare of less powerful people in a society (Agger, 1991).

Critical theory predominantly concerns with ideology, dominance, and liberation of social elites on disadvantaged people in a society. It is postulated that knowledge and social mechanism are developed, based on the economic, ideological, and cultural conditions in a society, and generally by privileged people in order to maintain their interests (Crotty, 1998; Oliver, 1992, 2002). In the process of knowledge production, researchers are not thought as being disinterested or unbiased but instead, they have personal ideologies and preferences. It is necessary thereby for stakeholders to question takenfor-granted ideas and reconstruct social mechanism to liberate the least powerful people from social oppression or dominance (Agger, 1991; Crotty, 1998; Mertens, 2005; Tyson, 2006).

Regarding the civic rights of disabled people, critical theorists tend to believe that the concepts of disability and disabled people and relevant mechanism are formed to serve the needs of mainstream people without disabilities while the needs of disabled people are inevitably ignored or sacrificed. Therefore, it is vital for disabled people to become knowledge producer and reconstruct social mechanism in order to emancipate disabled people from oppressive situations (Oliver, 1992, 2002; Stevenson, 2010).

Postmodernism is characterized by threads surrounding social constructionism, relativism and anti-grand narratives. Reality is seen as constructed by individuals and is situated to economic and cultural circumstances in a society. Therefore, it is subjective and relative, (Agger, 1991; Crotty, 1998; Mertens, 2005). Furthermore, postmodernism asserts that it is implausible to establish a grand narrative in interpreting human experience because all knowledge is limited, temporary, and fragmented, inclusive of postmodernism itself (Agger, 1991; Lyotard, 
1979). Traditional grand narratives, such as Christianity, Buddhism, Islam, Marxism and science are all invalid to interpret complex human experiences. Rather, postmodernists embrace the idea that each person can rely on his/her small stories to understand the world.

In a sense, in doing disability enquiry, it is critical for an individual to represent one's own life-story to challenge the interpretation of mainstream voices. Any person or group vowing to speak representatively for others or particular groups are regarded as an attempt to monopolize the voices and could lead to someone's voice being silenced (Agger, 1991; Crotty, 1998; Mertens, 2005).

Indeed, critical theorists and postmodernists differ in terms of attitudes towards the representativeness of common interests and plausibility of grand narratives. More specifically, critical theorists look forward to singular and unified huge narratives in explaining humane experience (Agger.1991). Meanwhile, postmodernist counterparts seek personal interpretation for life experience and refuse justification of political representation of any group or people (Heller \& Fehér 1988; Lyotard 1979).

\section{Implications for Research Methodologies}

Ideally, a research methodology is developed according to a philosophical epistemology. An epistemological position tremendously determines research purposes, research questions, and the researchers' relationships with research participants. In addition, the epistemological position determines the way to approach the questions, the types of data collections, the procedures of analyzing data and the formats of representing the results. In this section, three research methodologies; emancipatory research, DisCrit, and narrative research are introduced to show how critical theory and postmodernism are embodied into research methodologies for enquiring disability issues. Among them, the former two methodologies are influenced by critical theory and the latter is framed under postmodernism respectively.

\section{Emancipatory Research}

Emancipatory research stemmed from the critique on the inability of traditional positivist research and the medical disability model to eliminate or elevate the inequality disable people had experienced. Consequently, activism and social disability models are brought in to reshape research practice and social mechanism.
Oliver (1992) criticized positivist research as being alienated from disabled people in terms of three aspects. First, positivist researchers do not engage personal affections with participants in doing research. They do not stand by the disabled people and endeavors to remove relevant social barriers. Secondly, political consequences of knowledge are ignored. Positivist researchers see impairments as the main causes of being disabled rather than disabling social mechanism. Finally, positivist research does not yield actual actions for enhancing substantial living situations of disabled people. Thus there is a need to seek alternative methodology which emphasizes actual actions and new research relationship.

Emancipatory researchers also strongly question the medical disability model because it seems to dehumanize disabled people and situate them into the secondary position to mainstream people. The medical model recognizes students with disabilities as lacking of capabilities and lagging behind the norms and subsequently, some forms of compensations in non-inclusive placements become inevitable. To put it simply, disability stems from personal impairments and accordingly medical or psychological interventions are required to fix these problems (Barton, 2005; Stevenson, 2010; Walmsley, 2004).

Considering these problems, emancipatory research "seeks a fulfillment of the trinity of theory, practice, and action" (Mercer, 2002, p.232) to totally subvert existing knowledge and social mechanism related to disabled people. This requires two critical orientations: changing the hierarchical research relationship and altering research focus(Barton, 2005;Olive, 2002; Walmsley, 2004). In emancipatory research, disabled people are advanced as co-researchers and can decide upon the research questions, research procedures, sources of data collection, method of data analysis, and presentation formats of research results. It is argued that changing power relationship would lead to a reconstruction of knowledge system and social mechanism regarding disabled people. The second orientation is to view disabling society as the cause for a disability. It means that participation difficulties suffered by disabled people are attributed to environmental dysfunction and engage in a critical examination of social mechanism to emancipate them from social oppression (Barton, 2005; Mercer, 2002; Olive, 2002; Thomas, 2004; Walmsley, 2004;Wu, 2013).

\section{DisCridit}

Critical race theory is epistemologically based on critical theory and utilizes racial lens to critically examine 
the social mechanism and hopefully it will bring in the elimination of racial inequality (Ladson-Billings, 2000; Solórzano \& Yosso, 2002). Later, disability and other components of social scarifications are added to unravel their intersection with race. As to its research method, personal story (narrative) is deployed to unravel entangled interplay of race, disability, class, sex, etc. (Annamma, Ferri \& Connor, 2018).

It is argued that race is socially constructed and racism has been subtly and pervasively embodied into every aspect of a society, including education, law, media, literatures etc. (Milner, 2007; Ortiz \& Jani, 2010; Solórzano \& Yosso, 2002). For example, in the USA, racial inequality is embodied in public values. That is, the social values and behavioral criteria of the middle class. Whites are credited as the norm which minority people are wittingly or unwittingly enticed to obey or internalize (Kumasi, 2011). The racial inequality is also shown in the perspectives in explaining academic failures of minority students. Traditionally, biological differences were commonly argued for explaining academic failures of minority students; currently, however, cultural inferiority, such as parenting attitudes, students' learning attitudes and insufficient pre-knowledge is more often blamed (Love, 2004). Regardless of biological or cultural deficit perspective, it creates a dominant and subordinate relationship between mainstream people and minority people.

More recently, DisCrit provides an analytic framework in addressing the intersection of race and disability, such as over-identification of minority students as having disabilities or higher portions of minority students in noninclusive education environments (Annamma, et al. 2018). The interplay of disability and race is also found in educational context in Taiwan. For example, Wu and Chang (2015) indicated that Taiwanese aboriginal students were more likely to be diagnosed as having disabilities whereas they are less likely to be identified as being gifted or talented in comparing to non-aboriginal students.

In terms of its research method, multiple information sources, including storytelling, documents, literature, legal cases and drama can be used to represent the marginalized and oppressed experiences of minority people. The expressions of personal experiences are situated into the social contexts to interpret how historic, economic, cultural, and class conditions shape one's experiences. It is expected that this may help minority people to be aware of, to reflect, and to challenge social inequality (Jett, 2012; Ladson-Billings, 2000; Milner, 2007; Ortiz \& Jani, 2010; Solórzano \& Yosso, 2002).

\section{Narrative Research}

A narrative can be used as a method and is framed under different theories and disciplinary realms (Andrews, Squire \& Tamboukou, 2013). A method is a series of procedures used to conduct a study while narrative research goes beyond a method and is referred as a methodology, which includes theoretical assumptions and presuppositions of philosophical theory to justify the method of approaching research questions (Crotty, 1998). That is, a narrative is seen as a technique of data collection while narrative research includes the philosophical bases to justify the appropriateness of choosing narrative research. In this article, the concept of narrative research is based on the threads of postmodernism and is used to enquire the issues related to disability.

"A narrative is a story that tells a sequence of events that is significant for the narrator or her or his audience... Narrative, therefore, captures both the individual and the context" (Moen, 2006:4). Narrative research then aims to present, construct, explain, reflect, and reconstruct individuals' life stories. Atkinson (2004) stressed that a narrating process might enable people to understand and question their disadvantaged situations, and further challenge environmental restrictions or oppressions. Thus, narrating is viewed as an empowerment process.

Postmodernist narrative research seeks to present individual voices presenting different life stories as conforming to the goal of avoiding a singular or unified interpretation of disable people's lives (Heller \& Fehér 1988). The World Health Organization (2011) stressed that it is misleading to generalize the concept of disability and disabled people "because disabled people have different life experiences due to varied living conditions" (p.8). The multifaceted nature of social experiences is vital for policy makers to enact relevant policies and take political actions to alleviate welfare of disable people (Andrews et al., 2013).

Narratives could be demonstrated in three different forms: event-centered, experience-centered, and co-constructed narrative (Andrews et al., 2013). The event-centered narrative deploys oral interviews to explore the narrators' experiences, reflections or, attitudes to past events, while experience-centered narrative utilizes multiple data resources, such as documents, diaries, notes to present narrators' life stories, which could include past, present, and even future imaginations. These two types of narratives may be overlapping, yet the former's represented story could be more constant while the narrators may demonstrate variations in 
different time or circumstances. The third type of narrative focuses on the interaction process in building a story through conversations between narrators and interviewees or email exchanges.

\section{Conclusion}

Engaging various theories and methodologies into enquiring disability agenda could increase the understanding of multiple facets of social situations disabled people have experienced. This is a particularly emergent trend in ASEAN societies, given that positivist threads still dominate relevant discussions and consequently, issues of power, dominance and political consequences hidden in social mechanism and knowledge formations tend to be neglected. As discussed previously, applying emancipatory research, DisCrit and narrative research to research practice may be helpful in overcoming these problems.

Firstly, emancipatory research tends to use research as a political advocacy process where with researchers' help disabled people examine disabling society to subvert and reconstruct the existing knowledge and social mechanism. Secondly, DisCrit assumes that society is full of prejudice, stereotype and even discrimination against minority people. Therefore, this framework of DisCrist can be used to unravel the interplay of race and disability on the lives of disabled people. Finally, narrative research can be framed under postmodernism which opposes replacing existed knowledge system with another totalizing theory. Rather, each individual story is seen as a way for a disabled individual to represent and account personal experiences subjective to a macro society. Hopefully, involving different theories and developing multiple methodologies may provide more comprehensive angles to think of the situations and questions regarding disabled people and consequently their social situations could be changed.

\section{References}

Agger, B. (1991). Critical theory, poststructuralism, postmodernism: Their sociological relevance. Annual Review Sociology, 17, 105-131.

Andrews, M., Squire, C., \& Tamboukou, M. (2013). Doing narrative research (2nd). London: Sage

Annamma, S. A., Boelé, A. L., Moore, B. A., \& Klingner, K. (2013). Challenging the ideology of normal in schools. International Journal of Inclusive Education, 17(12), 1278-1294. doi:10.10 $80 / 13603116.2013 .802379$

Annamma, S. A., Ferri, B. A., \& Connor, D. J. (2018). "Disability Critical Race Theory: Exploring the Intersectional
Lineage, Emergence, and Potential Futures of DisCrit in Education." Review of Research in Education, 42(1): 46-71. doi:10.3102/0091732X18759041.

ASEAN. (2019, December 18). History. Retrieved from https:// asean.org/asean/about-asean/history/

Atkinson, D. (2004) Research and empowerment: involving people with learning difficulties in oral and life history research, Disability \& Society, 19(7), 691-702. doi:10.1080 /0968759042000284187.

Barton, L. (2005). Emancipatory research and disabled people: Some observations and questions. Educational Review, $57(3), 317-327$

Bentz, V. M. \& Shapiro, J. J. (1998). From positivism to postmodernity: the mindful inquirer as a philosopher. In Mindful inquiry in social research (pp. 15-35). Thousand Oaks, CA: SAGE Publications, Inc. doi: 10.4135/9781452243412.n2

Crotty, M (1998). The foundations of social research. Sydney: Allen \& Unwin.

Elkind, D. (1997). The death of child nature. Phi Delta Kappan, 79(3), 241-249.

Gabel, S., \& Connor, D. J. (2009). Theorizing disability: Implications and applications for social justice in education. In W. Ayers, T. Quinn, \& D. Stovall (Eds), Handbook of social justice (pp. 377-399). New York, NY: Erlbaum.

Gallagher, D. J. (2001). Neutrality as a Moral Standpoint, Conceptual Confusion and the Full Inclusion Debate. Disability \& Society, 16(5), 637-654.

Heller, A, \& Fehér, F. (1988). The Postmodern Political Condition. New York, NY: Columbia University Press.

Jett, C. C. (2012).Critical Race Theory Interwoven with Mathematics Education Research. Journal of Urban Mathematics Education, 5(1), 21-30.

Kauffman, J. M., \&Sasso, G. M. (2006). Toward ending cultural and cognitive relativism in special education. Exceptionality, 14(2), 65-90.

Kumasi, K. (2011). Critical Race Theory and Education: Mapping a Legacy of Scholarship and Activism. In B. A.U. Levinson (Eds.), Beyond Critique: Critical Social Theories and Education (pp. 196-219). Boulder, CO: Paradigm Publishers.

Ladson-Billings, G. (2000). Racialized discourses and ethnic epistemologies. In N. Denzin \& Y. Lincoln (Eds.), Handbook of Qualitative Research (pp. 257-277). Thousand Oaks, CA: Sage Publications.

Lee, L. W. \& Low H. M. (2014). The Evolution of Special Education in Malaysia. British Journal of Special, 41(1), 42-58

Love, B. J. (2004). Brown Plus 50 Counter-storytelling: A Critical Race Theory Analysis of the "Majoritarian Achievement Gap" Story. Equality \& Excellence in Education, 37, 227-246.

Lyotard, Jean-Francois. 1979. The postmodern condition. (Translation from the French by Geoff Bennington and Brian 
Massumi. Foreword by Fredric Jameson). Manchester: Manchester University Press.

Mercer, C. (2002). Emancipatory Disability Research. In L. Barnes, M. Oliver \& L. Barton (Eds.), Disability Studies Today (pp. 228-249) Cambridge: Polity Press

Mertens, D. M. (2005). Research and evaluation in education and psychology Thousand Oaks, CA: Sage.

Milner, H. R. (2007). Race, culture, and researcher positionality: Working through dangers seen, unseen, and unforeseen. Educational Researcher, 36(7), 388-400.

Moen, T. (2006). Reflections on the narrative research approach International Journal of Qualitative Methodology, 5(4), 56-59. https://doi.org/10.1177/160940690600500405.

Nishio, A.,Tomokawa,S., Kobayashi, J.,'Mizoue, T., Horita, R., \& Yamamoto. M., (2017). Inclusive education in Association of Southeast Asian Nations (ASEAN): Literature review from 1995-2015. School Health, 13, 20-29.

Oliver, M. (2002). "Emancipatory Research: a Vehicle for Social Transformation or Policy Development", 1st Annual Disability Research Seminar, NDA-CDS: http://www.leeds.ac.uk/ disability-studies/archiveuk/Oliver/Mike\%27s\%20paper.pdf.

Oliver, M. (1992). Changing the Social Relations of Research and Production?, Disability Handicap and Society 7(2), 101-114.

Ortiz. L. \& Jani. J. (2010). Critical race theory: a transformational model for teaching diversity. Journal of Social Work Education, 46(2), 175-193.

Solórzano, D. G. \& Yosso, T. J. (2002). Critical Race Methodology: Counter- Storytelling as an Analytical Framework for Educational Research, Qualitative Inquiry, 8(1), 23-44.
Stevenson, M. (2010). Flexible and Responsive Research: Developing Rights-Based Emancipatory Disability Research Methodology in Collaboration with Young Adults with Down Syndrome. Australian Social Work, 63(1), 35-50.

Thomas, C. (2004). How is disability understood? An examination of sociological approaches. Disability \& Society, 19(6), 569-583.

Tyson. L. (2006). Critical Theory Today: A User-Friendly Guide (1st). New York, NY: Routledge.

United Nations Economic \& Social Commission for Asian \&the Pacific (UNESCAP). (2012). Disability at a Glance 2012: Strengthening the Evidence Base in Asia and the Pacific. Bangkok: UNESCAP Social Development Division.The Economic and Social Commission for Asia and the Pacific. (2019, December 18)

Walmsley, J. (2004) Inclusive learning disability research: the (nondisabled) researcher's role, British Journal of Learning Disabilities, 32, 65-71.

World Health Organisation (2011). World report on disability. Retrieved from http://www.who.int/disabilities/world_ report/2011/en/index.html

Wu, C. C. \& Chang, C. S. (2015). Critiquing the Prevalent Rates of Aboriginal Students Requiring Special Need Education: A Perspective of Critical Race Theory. Special Education Forum, 18, 57-65. doi:10.6502/SEF.2013.15.20-32

Wu, C. C. (2013). A Critique on Discourse and Research regarding Inclusive Education: Taiwan as a Case Example. Special Education Forum, 15, 22-34. doi:10.6502/SEF.2015.18.57-65 